\title{
National Innovation and the Role of the College Sector
}

\section{CHARLES H. BÉLANGER}

Laurentian University

\section{JOAN MOUNT}

Laurentian University

PAUL MADGETT

Carleton University

IVAN FILION

Cambrian College

\section{ABSTRACT}

This paper discusses the role of the colleges in applied research in the context of Canada's capability for innovation in a globally competitive arena. The analysis focuses upon issues around an expanded mandate related to applied research. To explore the state of readiness of the college sector, it draws upon the results of a survey distributed to 150 college and institute presidents in Canada, as well as upon other recent studies. The discussion ends with suggested policy avenues to maximize the effectiveness of this sector's contribution to the nation's innovation agenda. 


\section{RÉSUMÉ}

Cet article discute le rôle que peuvent jouer les collèges en recherche appliquée alors que le Canada essaie d'accroître sa capacité à innover dans un contexte de concurrence mondiale. L'analyse est particulièrement ciblée sur les effets que pourrait avoir la reconnaissance de la recherche appliquée dans le mandat des collèges. L'article s'appuie entre autres sur une enquête distribuée à près de 150 présidents de collèges et instituts de même que sur d'autres études très récentes. Pour conclure, des pistes de politiques de recherche sont mises en évidence afin de maximiser la contribution du secteur collégial à l'efficience du dossier national de l'innovation.

\section{Introduction}

In the last forty years, a network of approximately 200 colleges was created in Canada to fulfill various roles related mostly to technical education, vocational training, and university entrance/transfer preparation. This trend was in response to a desire to bring technical, vocational, and post-secondary education closer to local communities and to an ever-increasing number of young and mature students. In midcourse, globalization emerged as a public policy imperative and began to challenge paradigms that had been designed solely for domestic purposes. The public at large started to link innovation with economic growth, and industrial/applied research with national productivity. As in many other countries, educational institutions took on new prominence. In popular parlance, they became "economic engines" for the advancement of Canada's economic competitiveness in the international arena.

The federal, provincial and territorial governments of Canada have made public a number of far-reaching goals to be attained by the year 2010 (Corkery, 2002a). These include to achieve a place among the world's top five countries in Research and Development performance; to develop at least ten internationally recognized technology clusters; to raise venture capital investments per capita to prevailing U.S. levels; and to bring the benefits of innovation to every part of the country - rural as well as urban. 
It is estimated that these commitments will require $R \& D$ investments of $\$ 48 \mathrm{~B}$ ( $\$ 26 \mathrm{~B}$ more than originally projected) by 2010 , and a cadre of 180 000 research scientists, engineers, and technicians (50000 more than the original target). In anticipation the Government has staged more than thirty national innovation summits to speak to the education, business and academic leaders in their respective communities.

The Canadian economy in its present state displays both singular characteristics and particular challenges. Corporate ownership in Canada by Canadians has been described as 'oligarchic' (e.g., Taylor, Warrack and Baetz, 1999), and as such not systemically conducive to effective competition, and consequent innovation. Further, foreign direct investment or ownership, and control stand at a very high level. As a result, R\&D more often than not occurs outside of the country, and has little or no impact on the economy of this country. Third, Canada's overall level of innovation capacity is ranked $6^{\text {th }}$ among the G- 8 and is still referred to as an "innovation gap" by OECD (2001), based on a number of indicators, including government- and business-funded expenditure on R\&D as a percentage of GDP. Also, funding patterns over time in this country have focused on basic research ${ }^{1}$ to a much greater extent than on applied research closer to the commercialization stage (Ivany, 2000). Otherwise stated, developing new technologies and bringing them to market through small and medium size enterprises (SMEs) have not been prominent goals.

The last five years, in Canada as elsewhere, have seen an insistent thrust for greater participation in applied research by the tertiary education sector. The OECD's report Redefining Tertiary Education (1998), is a compelling invitation to mobilize the full gamut of resources in the higher education field. Its authors assert that attempts to keep tertiary non-research institutions away from R\&D activities have generally failed over time, mainly because many teachers view research activity as a sphere hospitable to their specialized knowledge, and their creative propensities. In the same vein, Ivany (2000) argues that the above circumstances call for colleges to play a more active role in applied research, just as earlier they moved into customized training functions in response to local/regional business needs. He sees a close match between the skill sets of college faculty and the practical hands-on nature of applied 'commercialization stage' research, 
without encroachment on the current role of universities. In an indirect reference to universities, he adds that "in the current environment, there can be no monopoly on the creation of new knowledge".

The Association of Canadian Community Colleges (ACCC), a national body which draws together approximately 150 of Canada's colleges and technical institutes, has prescribed to government officials the roles it sees for colleges/institutes within this country's evolving industrial research mosaic. These include assisting in product and process development; providing industry access to equipment and pilot plants; building awareness of new and best practice technologies; providing access to resource centers; assisting with market and product feasibility assessments; and supplying input to business planning (ACCC, 2002a).

\section{Background and Context}

Should one be surprised that educational institutions created to fulfill the particularities of one period have been confronted with the challenges of reshaping and retooling themselves as societal currents shift the emphasis from traditional needs and roles, and prompt new ones to emerge - just as in other areas of the corporate world and society in general? A rhetorical question perhaps, and yet it speaks to a phenomenon that breeds uneasiness in many circles. This uneasiness is captured by phrases such as 'encroachment on the role of universities' and "academic drift". Historically there has been a pattern of non-university institutions taking on the likeness and even eventually the title of universities.

Whether or not one uses the label 'academic drift' as coined by Burgess (1972), there are plenty of examples and the process is strikingly similar. When, in 1960, the California Legislature adopted its then controversial three-layer system of public higher education, it formalized a structure consisting of the University of California, state colleges, and public community colleges. The aftermath was a persistent striving by the state colleges for enhanced status (see the Carnegie Commission, 1971 for details). When New York, which had the second largest network of state colleges in the USA followed suit, there was no reversing the American mass higher education movement.

The second part of the 1960s was also a time of effervescence in 
Europe, as students vociferously demanded more accessibility to, and relevance in, higher education. Many countries responded with the creation of new institutions. In Great Britain the polytechnics were established, in France the instituts universitaires de technologie, in Germany the fachhochschulen. Similar entitites emerged in many other Western countries including Belgium, Netherlands, Ireland, the Scandinavian countries, and Australia. In recent years many of these institutions have acquired, or come close to, the equivalent of university status through assorted forms of amalgamation and integration (Kyvik, 2001; Kyvik, 2002). Generally speaking, "established universities" vigorously opposed this phenomenon, castigating it as political advocacy to take on "the less gifted".

Barring the odd exception resulting from structural amalgamation or other clearly identifiable and specific mandates, institutions in Canada's college sector were not established to be involved in the systematic production and dissemination of research - applied or basic - but rather to provide specialized occupational skills, to address regional labor market needs, and to make university entrance preparation more accessible. However, in the last 10 years, some larger colleges, mostly urban, have led the charge to carve a more conspicuous and aggressive role for this sector within the national research and innovation agenda (Ivany, 2000; Julien, 2002).

In brief, some colleges and institutes in Canada, but by no means all, envisage themselves at the forefront of industrial research, technological innovation, and product commercialization, serving as the bridge between universities and industry. Given an ambitious government strategy, and the eagerness on the part of some colleges to participate in the applied/ industrial research/technology component, there is an urgency surrounding questions about the mandate of the colleges and their role with respect to applied research. The issue that drives the present discussion is one of how to harness optimally the potential research capacity within the national system, as urged by the OECD Report Redefining Tertiary Education (1998), without sacrificing the hitherto defining roles of universities and colleges respectively, nor falling into "affirmative action" initiatives that could dilute scarce research dollars and research products. Informed by data from a variety of studies, including their own recent survey of 
College/Institute presidents (2003), the authors examine various elements of the contextual evolution leading to the current and potential mandate of the college sector.

\section{College Sector Involvement in Applied Research}

Colleges, and institutes where these exist, claim to link with some 900 communities in Canada. With particular ties to local economic development agencies, they have a well-entrenched involvement in local/regional development initiatives. It is therefore clearly misleading to depict applied research as a "new" activity for the college sector. It has been customary to align individual colleges and institutes with particular regional industry and axes of economic development (Julien, 2002). Admittedly the scope of this activity may be modest, and specific to a single institution. As a network, however, they count today approximately 50 Applied Research/ Technology Transfer Centres, employing close to 1000 faculty and support staff associated with these Centres. These entities received collectively government and private funding in the order of $\$ 150 \mathrm{M}$ annually for research, infrastructure, equipment, and networks (Corkery, 2002a). The multi-faceted mandate of these Centres is to conduct applied research to meet SME needs, to disseminate research results through technology transfer, to carry out intelligence activities for businesses, to establish research networks with universities and other agencies, to offer employee training programs, and to provide consultancy/mentoring/brokerage services (Corkery, 2002b). Many of these Centres have successfully created spin-off companies.

At the same time the very existence of research activity in the college sector is remarkable considering the impediments to be overcome. Conspicuous among these obstacles are the following three:

a) none of the 10 provincial legislatures which passed the respective "College/Institute Act" had included R\&D as a component of a teacher's workload, or as an institutional duty. The 2002 amendment of the Act in Ontario now mentions applied research as one of its objectives. Notably, the handful of colleges in Canada's territories, where no university exists, have long been charged with the responsibility of supporting some research infrastructure. 
b) none of the 10 provincial legislatures recognizes or explicitly funds $\mathrm{R} \& \mathrm{D}$ within colleges per se. Current operating grants are based on enrollment in approved programs, and colleges make internal allocations as they see fit.

c) college/institute collective agreements do not recognize $\mathrm{R} \& \mathrm{D}$ as a duty, nor as a lever for promotions and bonuses under the terms of employment, with the exception of some special arrangements within colleges situated in the territories and a few university colleges. The latter typically display a hybrid identity embracing rules and networks for both college and university.

Other internal barriers exist such as heavy teaching loads and a lack of infrastructure to nurture a research culture.

\section{Creating Research/Knowledge Capacity}

Although the tie between the system of knowledge production and a country's economic development may be recognized, there is no straightforward recipe for strengthening the knowledge generating system. It is a complex entity, dependent upon elements such as previous performance, current infrastructure, available expertise, and sociopolitical factors. Not surprisingly, a number of studies have underlined its fragility. For instance, Barnett (1993) perceives a tendency to buttress existing research cultures, hence engendering intellectual isolation and fragmentation instead of new ways of thinking, new paradigms. Similarly Crossley and Holmes (2001) decry intellectual myopia when they argue that global problems and local issues cannot be isolated one from the other, and therefore require multi-faceted analysis that draws in both. The works of Rist (1994) and Ball (1998) speak to the threat that research results, once disseminated, may be downplayed or ignored. They contend that in many systems research findings are marginalized in the policy-making process, especially those that do not concur with the political agendas of influential decision-makers.

Historically, the adoption of research as a core function within the university sector is a comparatively recent development. While individual research activities in universities can be traced back to the twelfth century, 
the integration of teaching and research, particularly basic research, was institutionalized as a core function only after World War II. The discipline-based von Humboldt model made universities the primary locus ("factories") of knowledge production and transmission, and equally the arbiter of "good science" by virtue of their intellectual capital and adherence to a set of scientifically accepted research practices.

Today universities of all types have lost some luster as the "conscience of society" and as knowledge depositories in that they have now become only one among the several actors involved in the production of knowledge. Gibbons (1998) points out that the number of potential sites where knowledge can be created is no longer only universities, but extends to many arenas, including non-university colleges/institutes, research centers, government agencies, industrial laboratories, think tanks, and consultancies. A variety of interactions may occur. He also makes clear the distinction between knowledge generation for its own sake and knowledge intended for practical application, speaking specifically of the latter as knowledge intended to be useful to someone whether in industry, government, or society at large, and organized and judged on sometimes different, sometimes additional criteria to that of basic research.

Gibbons'work strongly endorses the emergence of a more encompassing arena of knowledge generation that admits a practical/applied approach and goes beyond the university setting. Corroborating Gibbons' perspective is analysis done by the World Bank (1998) and by researchers such as Crossley and Holmes (2001) which examines knowledge production capacity in contexts varying from small states in the U.S.A. to developing countries. The importance of this enlarged focus is highlighted in studies such as those by Pavitt (1991) and Williams (1986). The latter have emphasized that a nation need not be a leader in basic research to stand out in the production and utilization of technologies. Factors such as skill development, partnerships, and early experimentation and adoption of new technologies all serve to fuel the innovation process. As stated in the introduction, an important issue for the tertiary education system is one of how to marry the potential research capacity across universities and colleges while maintaining key distinctions in mandate. 
In an effort to establish a frame of reference for policy formulation, to tap dimensions untouched in previous data collections, and to verify a range of statements made by various advocacy groups, the authors conducted a survey with all 150 college/institute presidents whose institution belongs to the national Association, ACCC. The survey was sponsored by and distributed through this same Association, although ACCC did not control the survey content.

More specifically, the intent of this survey of College/ Institute heads was to: a) assess the extent to which there is a willingness on the part of colleges to engage in applied research, and in particular a concerted plan; b) understand the factors that prompt colleges to take up this activity; c) determine the state of readiness (strengths, weaknesses, obstacles, etc) of colleges to embrace this additional undertaking; and d) analyze the pros and cons of such direction in terms of optimizing a national research policy. A variety of techniques were used in the questionnaire such as dichotomous questions, constant-sum scales (over 100\%), ranking preferences, and fivepoint Likert scales. With respect to this last technique, the "substantially" and "very substantially" responses were merged and are reported together in this discussion.

The authors' 2003 survey, with a $24 \%$ response rate (which covers approximately 50 campuses given the fact that in some provinces, the response was filed on behalf of the provincial system), is complemented by three other recent studies. The latter were undertaken under the auspices of Industry Canada, a department of the federal government (Corkery, 2002a; Corkery, 2002b; ACCC, 2002b). These three studies were the first systematic attempts to inventory system wide aspects of $R \& D$ activities in Canadian colleges and institutes. In addition to basic data on faculty, enrollment and programs, they include general information such as the number of spin-offs, prototypes completed, licenses, patents, specifications on R\&D structure and infrastructure, current assets and impediments to applied research activities. By examining these four ACCC endorsed studies, one can with relative confidence offer observations bearing upon the role of colleges within the tertiary education system. 


\section{Perception and Potential: Room for Redefinition}

Discussion of the potential contribution of the two different sectors, university and college, might usefully begin with the terms "research" institution and "non-research" institution, and the perceptions associated with these terms. Loosely applied to label universities of "whatever so-called tier" and colleges respectively, these terms have been tellingly used to distinguish between the two. Arguably this form of labeling reinforces a variety of perceptions about what is "right and proper" activity for each type of postsecondary institution. The authors identify below two commonly held perceptions associated with universities and two with colleges. Each perception in turn comes under scrutiny in the light of recent survey findings and pertinent literature.

\section{Perception \# 1: Universities have a proprietary and unassailable role as generators of research.}

When examining this perception, one must make reference to the societal context. In the global economy, technological innovation is seen to depend increasingly upon specialized expertise to address competitive pressures. Obviously, the problem focus need not be solely commercial in nature but could relate to a number of social spheres such as ecology, health, urbanization, and ethics, where money is only one of many considerations. Who is competent and capable of contributing to such knowledge and innovation production? A comparative analysis of problem solving which is carried out following the codes of practice relevant to a particular discipline on the one hand, and problem-solving which is organized around a particular application on the other, leads to two entirely different formulas. In the discipline-oriented context typical of the university setting, the value of research is often judged by the success of funding applications to the national granting agencies. Success depends on criteria such as the significance of projects (academic/scientific as well as socio-economic), scientific approaches/methods, novelty, quality of the research teams in terms of academic qualifications, publications records, and experience in the academic training of graduate students. In contexts other than the university, the value of research normally begins 
with questions of direct relevance to potential users of the prospective knowledge, often with the ultimate test set in the marketplace, and with response time in reaching a solution being an imperative. These questions include "Will the solution to a particular problem, if found, be competitive in the market? Cost effective? Socially acceptable?" Rather than being governed by the strictly defined rigors of an academic discipline and review by academic peers, quality control rests on a more composite, multi-dimensional evaluation. Typically a key attribute is flexibility of application. Further, the diffusion of the resulting knowledge occurs not through scientific journals or professional conferences but as the original practitioners move on to new physical contexts.

Researchers committed to basic disciplinary research are not the most adept necessarily at conducting applied/transdisciplinary research, nor at assessing its results. According to authoritative sources such as Gibbons (1998), the World Bank (1998), and the OECD (1998), a nation also needs a contingent of knowledge workers - problem identifiers, problem solvers, and problem brokers - who understand the crucial role of knowledge in dynamic markets and who bring "specialist knowledge" to bear on a firm or an industry's comparative advantage in international competition. This is an unequivocal call for a complementary approach focused on practical application.

Within the college sector today, individual colleges and institutes sit at different places along a continuum of involvement in applied research, with some institutions clearly poised to challenge the monopolistic claim implicit in the perception 'universities have a proprietary ... role as generators of research'. Specific to a question in the authors' 2003 Survey of college and institute presidents, two out of three institutions do participate in some form of applied research. Forty four percent of the colleges have included applied research in their Mission Statement and their Governing Board's written policy. About the same percentage have an approved Applied Research Plan (see Table 1).

The authors' 2003 survey also revealed the views of college/ institute heads on the overall relationship between research done in the universities and that conducted within their own sector. 
Table 1

\section{Internal Policy Framework}

\begin{tabular}{lcc}
\hline & Yes & No \\
\hline $\begin{array}{l}\text { Does your Institution's Mission Statement make specific } \\
\text { reference to Applied Research? }\end{array}$ & $44 \%$ & $56 \%$ \\
$\begin{array}{l}\text { Does your Institution's Governing Board have a written } \\
\text { policy statement on Applied Research? }\end{array}$ & $44 \%$ & $56 \%$ \\
$\begin{array}{l}\text { Does your Institution have an Applied Research Plan? } \\
\begin{array}{l}\text { Do you think that engaging in Applied Research } \\
\text { enhances the prestige of your Institution? }\end{array}\end{array}$ & $53 \%$ & $47 \%$ \\
\hline
\end{tabular}

Fifty three percent (53\%) regarded the college research focus as complementary to, rather than in competition with, that of universities. Twenty eight percent (28\%) perceived some overlap with universities while $16 \%$ saw little or no relationship with universities. Only three percent deemed the overlap to be substantial. One can predict that the respondents would agree that an effective national innovation strategy must acknowledge the need for both basic and applied research. At the same time, half of the respondents to the authors' 2003 Survey indicated that the college/institute sector in Canada does not yet have a clear vision of its own role in applied research, even though $81 \%$ met provincially and $66 \%$ did the same nationally to discuss this specific question.

\section{Perception \# 2: Because of their unique research capabilities, universities are entitled to the lion's share of government R\&D funding.}

Clearly this perception is closely related to the first. Over time this view has been reinforced by the prevailing funding practices. The traditional division of domains and the associated funding patterns - Natural Sciences 
and Engineering, Social Sciences and Humanities, and Health - have leaned heavily towards basic/disciplinary research. With respect to applied research, the authors' 2003 Survey of college/ institute heads revealed the centrality of external funding. Government Research Funding ranked as the lead external factor for engendering interest in applied research in their sector. Interestingly, it was followed closely by the Needs of Local Industry. The juxtaposition of these two factors warrants some attention for it is reinforced in recent high profile public funding initiatives that have disbursed significant research dollars to the tertiary education sector. These initiatives provide notable support and legitimacy for applied research and the alignment thereof with the needs of industry. Gibbons (1998) observed that knowledge that is deliberately generated for practical application occurs characteristically through ongoing dialogue, from the beginning, between producers and users. Noteworthy in this context is the close relationship which Colleges and Institutes typically nurture with their communities, a type of outreach now mandated explicitly by various levels of government.

At a greater level of specificity, the funding format of the Canada Foundation for Innovation and of flanker initiatives such as the Ontario Research and Development Challenge Fund and the three similar Quebec research funds obliges researchers to forge links with industry. These programs joined the National Research Council's on-going Industrial Research Assistance Program (IRAP) already in place specifically to assist the SME sector. The widely held conviction that R\&D leads to innovation, then to economic growth, and ultimately to improved regional and national economic performance has become coupled with an explicit funding format.

Clearly, given the potential level of college sector involvement in applied research, the position that unique research capabilities entitle universities 'to the lion's share of government R\&D funding' should, and will, come under scrutiny. Already a three-way partnership program involving colleges, NSERC, and the Canadian Manufacturers and Exporters was announced in early 2004. Although the fund represents only $\$ 3.6 \mathrm{M}$, the debatable issue may be whether this money has been "taken away" from universities, given that no additional dollars were put into 
the NSERC share. A timely question might be: At the national research policy level, should there be distinct college stream and university stream funding? A supplementary but clearly contentious question would then be "In what proportions should the funding pie be divided?" Are universities entitled to the lion's share? Is this an ontological argument?

\section{Perception \#3: Colleges and institutes have discovered in applied research and technology transfer a manna waiting to be picked.}

It would be naive on the part of the college sector to assume that universities have not moved heavily into the world of spin-offs and commercialization. A notable minority of university researchers do not wait for the lengthy processes of national and institutional research funding to take their course. Instead they look to external business partners for ever more robust financial support. The scenario framed by Matkin (1990) whereby universities would embrace technology transfer activities as part of their core mandate has transpired in some measure, notwithstanding the accusation from some alarmed academics that senior administrators are auctioning university values to the highest bidders - a charge administrators would deny (Mount and Bélanger, 2001). Largely since the time of Matkin's writing, a number of universities have established arms-length centres in order to capitalize specifically on applied research opportunities. Problem solving teams with heterogeneous skills and experience interact directly with clients to solve problems that are often of pressing commercial relevance. These Centres draw upon the expertise of those faculty who choose to participate and exhibit the hallmarks of applied knowledge generation discussed earlier.

At the same time colleges/institutes are strategically positioned to secure contracts for applied research. They continue to be, by virtue of their mandate, geographical dispersion, and closeness to their respective communities, the primary providers of employee training. In this role they help SMEs in particular to hone their commercial capacities and in many cases to adopt leading-edge technologies. This training function is executed by a teaching staff with unique practical skill sets. Not unexpectedly these same skill sets may be harnessed to develop prototypes, test products, 
and finalize designs. These activities may not be seen by a number of university researchers as "good science". Nevertheless, they may prove vital for attaining national prominence for innovativeness.

In order to assess the extent to which colleges and institutes might be motivated to pursue applied research, the authors' 2003 Survey set out a battery of possible outcomes related to such involvement and asked how desirable each outcome was deemed to be. Table 2 displays the six most desired. It also reports the extent to which each is perceived to be occurring at present.

Table 2

\section{"Desirable" Outcomes Versus "Now Occurring" Outcomes}

\begin{tabular}{lccc}
\hline \multicolumn{1}{c}{ Outcome } & Desirable & $\begin{array}{c}\text { Now } \\
\text { Occurring }\end{array}$ & Gap \\
\hline $\begin{array}{l}\text { Students' Participating in R \& D } \\
\text { Increased Status via à vis Other }\end{array}$ & $72 \%$ & $8 \%$ & $64 \%$ \\
$\quad$ Colleges & $63 \%$ & $22 \%$ & $41 \%$ \\
$\begin{array}{l}\text { Increased Status via à vis Other } \\
\text { non-University institutions }\end{array}$ & $58 \%$ & $20 \%$ & $38 \%$ \\
$\begin{array}{l}\text { More Emphasis on Economic } \\
\text { Development }\end{array}$ & $58 \%$ & $27 \%$ & $31 \%$ \\
$\begin{array}{l}\text { Recruitment of Research Faculty } \\
\text { Development of Degree }\end{array}$ & $54 \%$ & $19 \%$ & $35 \%$ \\
Programs & $52 \%$ & $35 \%$ & $17 \%$ \\
\hline
\end{tabular}

Arguably desired outcomes, not yet realized, provide impetus for increased institutional involvement in applied research. Surprisingly, financial outcomes such as Revenue Generation (Patents, Spin-offs, etc) and the Prospect of More Infrastructure Funding do not rank among the top six. Manna, if thus defined, may not be a big inducement at this time. Compelling enticements nonetheless do exist, related in particular to perceived status. Four out of five $(83 \%)$ of the presidents asserted that 
applied research would enhance the overall prestige accorded the college sector to a "substantial" or even "very substantial" degree (see Table 1).

\section{Perception \# 4: Colleges will be distracted from their core function if their mandate officially expands to include research.}

History tells us that non-university tertiary institutions (state colleges, polytechnics, technikons, fachhochschulen, etc), although initially positioned as clearly distinct from universities, tend in many cases to adopt university-like norms. With time many came to embrace the disciplinebased knowledge production form and individual performance mode that is encouraged by reward mechanisms which are based on published output, such as progress through the salary scale, promotions, and release time for research. Note that such internal rewards are reinforced by those of the national basic research funding bodies (Rowley, 1999). Almost inevitably, such institutions aspired eventually to university status. With respect to this phenomenon in Canada today, there are signs of growing overlap. The development of degree programs is not only a desired outcome, according to the data from the authors' 2003 Survey, but is now occurring to a notable extent. Here one can pose a chicken and egg question: to what extent is pursuit of degree programs a function of applied research, and to what extent is interest in applied research a function of the emerging degree programs?

Occupational preparation was the core objective for the creation of colleges in the "old" economy. To explore the present level of commitment to this objective, the authors' 2003 Survey asked college/institute heads to rank their top three institutional priorities. Eighty five percent $(85 \%)$ of the respondents stated that Education/Training/Skills Development was their institution's top priority. Only three percent (3\%) of the respondents put Applied Research at the top of the priority list, before training and skill development. At the same time many colleges operate R\&D and applied technology transfer centres, receive contracts from local business, and cultivate links with area SMEs. As second level priorities Support to SMEs ( $40 \%$ of respondents) and Applied Research (35\%) each received relatively strong endorsement. It is noteworthy that the centrality of 
Education/Training/Skills Development is bolstered by the current funding formula. Table 3 reflects the relatively slight extent to which college/ institute presidents perceive realignments in earlier priorities and in-house resources to be occurring, or desirable.

Table 3

“Now Occurring" Outcomes Versus "Desirable" Outcomes

Now

Outcome Desirable Occurring Diff.

$\begin{array}{llll}\text { In-House Re-Allocation of Resources* } & 20 \% & 11 \% & 9 \% \\ \text { De-emphasis of Earlier Priorities } & 15 \% & 13 \% & 2 \%\end{array}$

* Applied research funding typically displays the following configuration: self-generated cost recovery contracts $(40 \%)$, provincial agencies $(25 \%)$, federal departments $(20 \%)$, and internal resource re-allocation (15\%) (Source: Authors' Survey 2003).

How do we preserve the unique character of colleges/institutes and also give them official recognition for their role in and contribution to applied research/technology activities? It was previously said that neither provincial legislatures nor college collective agreements endorse research as an essential workload component for college faculty. From a practical perspective individual colleges must provide, and must be themselves resourced to provide, the internal elements that stimulate or support $\mathrm{R} \& \mathrm{D}$ activities, i.e. the enabling resources. One obvious adjustment is in the area of workload. At present teaching staff in the college sector, unlike faculty members at the university, have no time component in their workload for research activity. While the systemic allotment of unstructured time for research may be prey to some abuse (Jauch and Glueck, 1975; Liebert, 1977; Bélanger, 1990), university professors in North American universities normally have a $25-40 \%$ research component built into their workload, within which is supervision of graduate students. Typically this time component is augmented by cyclical sabbatical leaves for research purposes. While the university pattern does not fit the college sector, a workload formulation appropriate to the specifics of teacher/researcher in 
the college context is essential. At a broader level of generality, there are some basic requirements for optimizing research productivity. Figure 1 exhibits the extent to which some of them are in place today in colleges. The importance of these enabling assets must not be discounted. When college presidents were asked to quantify the degree to which each of the elements listed in Figure 1 is currently in place, they responded, as examples, that "modulated faculty workloads" was only at $20 \%$ of its potential whereas "Support from senior management" stood at $83 \%$.

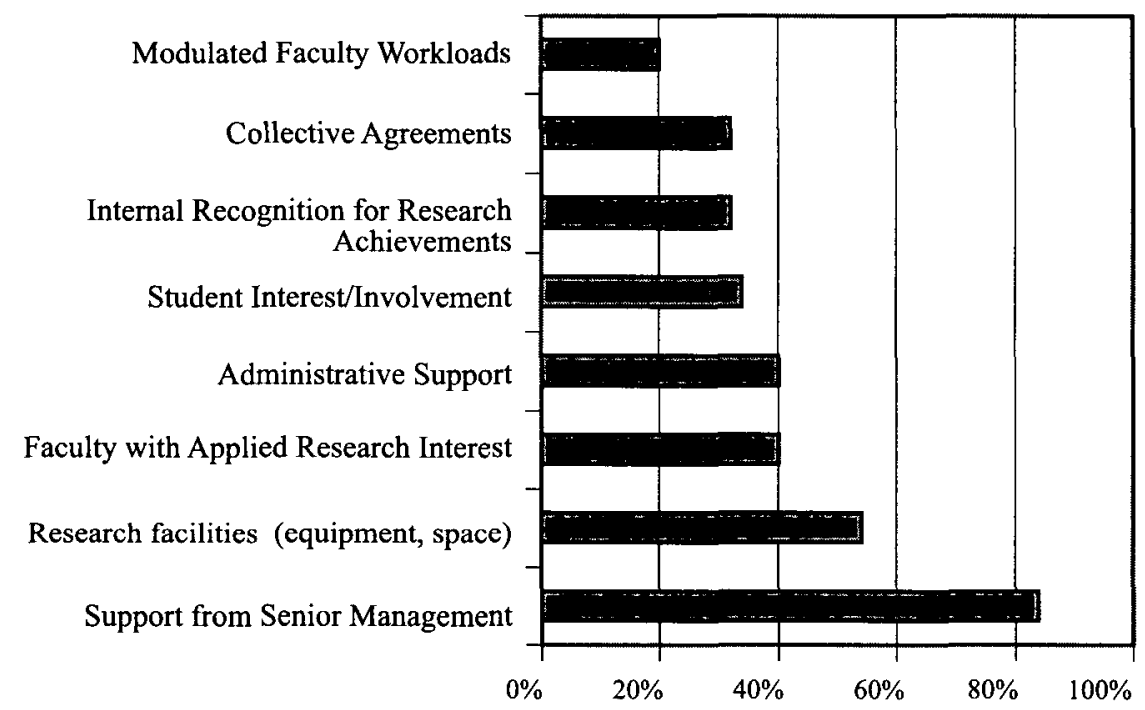

Figure 1. Current Enabling Assets for Supporting Applied Research

An example of creative improvisation with respect to enabling assets lies in a model provided by the 29 College Technology Transfer Centres established in the Province of Québec since 1983. The Québec General and Vocational Colleges Act formalizes college research through armslength centres in 12 regions of the province, carefully matched with regional strengths. The Québec government invests about $\$ 10 \mathrm{M}$ per year in these Centres. Approximately double this amount comes from the private sector. Release time for individual college faculty involved in the Centres is negotiated by faculty unions. 


\section{Perspectives and Conclusion}

Canada's innovation agenda has become more aggressive. The view that universities maintain a quasi-monopolistic stronghold on the entire field of research is not only passé but retrogressive and counter productive. The primary goal must be an innovation strategy that will mobilize all possible resources and lead to a competitive advantage for Canada. Some, although by no means all, colleges are adopting applied research/ technology as a substantial sphere of activity. Clearly, any organization that has something to offer to a national innovation agenda must be given the chance to channel its contribution. Within the tertiary education sector lies the capability to generate specialized knowledge that is both difficult to imitate by competitors and too expensive to reproduce in-house by SMEs. The present challenge is to acknowledge the legitimacy of various types of contribution, and accord recognition to each.

Arguably the time is ripe for an integrative approach supported by all stakeholders including Government. Rather than colleges vying with universities, and hence precipitating a "hold fast" posture on the part of the latter, the tertiary education sector as a whole should be encouraged to join forces in a mutually reinforcing partnership. These authors believe that establishing segregated funding streams would discriminate against research players or projects which transcend neat categories, and would not necessarily be conducive to research excellence. It is more logical to determine clear criteria at the outset for basic and applied research/ technology, to establish the appropriate mix of adjudicators, and then to fund the projects that best meet these criteria. However, to recognize the fact that universities and colleges have overlapping activities and to bring a broader range of knowledge to the table, it might be fruitful to envisage a new stream of "joint research only". Ideally researchers from both types of institution would form partnerships of equals making complementary contributions.

Speaking broadly, the college sector in Canada is reassessing its mandate at the present time, a mandate which has traditionally consisted of skill development and training. Each geographical jurisdiction must be given the prerogative of finding the best solution for its college system, taking into account the expanding emphasis on applied research, at local and 
national levels. Also redefinition must occur within the perspective of the total tertiary education mosaic. This challenge requires the collaboration of all the stakeholders, principally colleges/ institutes, universities and the government. Both types of institutions have distinct and crucial roles to play. In the end a judicious blend of central policies and local solutions will probably work best.

\section{Notes}

'For compilation or inventory purposes, the OECD Frascati Manual (1993) attempted to define what constitutes R\&D by breaking it down into basic research, applied research, and experimental development, with the caveat that those three components are often blurred in scientific fields. 


\section{References}

ACCC. (2002a). Supporting Canada's innovation strategy-ACCC Proposal. Ottawa: The Association of Canadian Community Colleges.

ACCC. (2002b). Survey of college and technical institutes' applied research and development activity. Ottawa: The Association of Canadian Community Colleges and Industry Canada.

Ball, S. (Ed.) (1998). Comparative perspectives in education policy. Comparative Education, 34(2), Special Number 20.

Barnett, R. (1993). Knowledge, higher education and society: a Post-modern problem. Oxford Review of Education, 19(1), 33-46.

Bélanger, C. (1990). Faculty performance and workload inequity. Higher Education Management, 2(2), 115-123.

Burgess, T. (1972). The shape of higher education. London: Cornmarket Press.

Carnegie Commission on Higher Education. (1971). New students and new places. New York: McGraw-Hill Book Company.

Corkery, K. (2002a). Colleges and the National Innovation Agenda. Ottawa: Strategic Policy Branch, Industry Canada, Government of Canada.

Corkery, K. (2002b). Provincial and territorial profiles: Community colleges and technical institutes. Ottawa: Strategic Policy Branch, Industry Canada, Government of Canada.

Crossley, M. and Holmes, K. (2001). Challenges for educational research: International development, partnership and capacity building small states. Oxford Review Education 27 (3), 395-409.

Gibbons, M. (1998). Higher education relevance in the 21st Century. Paris: UNESCO World Conference on Higher Education.

Government of Canada (2001). Achieving excellence: Investing in people, knowledge and opportunities. Ottawa: Industry Canada.

Government of Canada (2002). Canada's Innovation Strategy. New ideas. New opportunities. Ottawa: Government of Canada, Industry Canada.

Government of Canada (2002). Canada's Innovation Strategy. New ideas. New opportunities. Ottawa: Government of Canada, Industry Canada.

Ivany, R. (2000). Economic development \& a new millennium mandate for Canada's community colleges. College Canada, 5(1), 10-13.

Jauch, L. R. and Glueck, W. F. (1975). Evaluation of university professors' research performance. Management Science, 22(1), 66-75. 
Julien, C. (2002). Le collégial: Dans les plates-bandes des universités. Découvrir, 23 (3), 55-61).

Kyvik, S. and Skodvin, O.-J. (2001). Research in non-university higher education sector tensions and dilemmas. Porto: 23rd EAIR Forum.

Kyvik, S. (2002). Changing relationships between university and nonuniversity higher education sectors. Prague: 24th EAIR Forum.

Liebert, R. J. (1977). Research-grant getting and productivity among scholars. Journal of Higher Education, 48(2), 164-192.

Matkin, G. W. (1990). Technology transfer and the university. London: Macmillan.

Miner, R. (2002). Research matters but do colleges? A note to NSERC.

Mount, J. and Bélanger, C. (2001). 'Academia Inc.': The perspective of university presidents. The Canadian Journal of Higher Education, 31(2), 135166.

OECD (1993). The measurement of scientific and technological activities. Paris: OECD.

OECD (1998). Redefining tertiary education. Paris: OECD.

OECD (2001). Main science and technology indicators. 2001:2.

Pavitt, K. (1991). What makes basic research economically useful? Research Policy, 20, 109-119.

Rist, R. (1994). Influencing the policy process with qualitative research. In N. K. Denzin and Y. S. Lincoln (Eds.), Handbook of Qualitative Research (pp. 545-557). London: Sage.

Rowley, J. (1999). Developing research capacity: The second step. The International Journal of Educational Management, 13(4), 208-213.

Taylor, W. D., Warrack, A. A., and Baetz, M. C. (1999). Business and government in Canada: Partners for the future. Scarborough, Ontario: Prentice Hall Canada Inc.

Williams, B. (1986). The direct and indirect role of higher education in industrial innovation: What should we expect? Minerva, 24(2/3), 145-171.

World Bank (1998). World Development Report: 1998/99 - Knowledge for development. Washington D. C.: The World Bank 